\title{
BETWEEN MAGDALENIAN AND EPIGRAVETTIAN. A CONTRIBUTION TO THE STUDY OF THE PALAEOLITHIC ON THE POLISH-UKRAINIAN BORDER
}

\author{
Dariusz BOBAK $K^{1}$, Marta POETOWICZ-BOBAK \\ ${ }^{1}$ Rzeszów Archaeological Centre Foundation, \\ Moniuszki St., 10, 350015, Rzeszów, Poland, e-mail: dbobak@lithics.eu \\ ${ }^{2}$ University of Rzeszów, \\ Moniuszki St., 10, 350015, Rzeszów, Poland, e-mail: mpoltowicz@lithics.eu
}

The terrains of Poland, located north of the Carpathians and the Sudetes, have been almost completely abandoned during the period of the LGM sensustricte.

The reoccupation of Polish territories took place not until the end of LGM. These areas were then settled by the societies of the Magdalenian complex - a tradition that included upland areas of Western and Central Europe. On the basis of today's state of knowledge, it can be concluded that the eastern borders of Poland are at the same time the eastern boundary of the Magdalenien settlement.

Five Magdalenian sites from the areas of today's Podkarpackie Voivodship are known (fig. 1). In the 1940s, a single-row harpoon linked to Magdalenian was found in Przemyśl. Further discoveries of sites fall into the turn of the 20th and 21st centuries. Four of the mhave been discovered up to this day: in Hłomcza, Grodzisko Dolne, Wierzawice and Łąka.

This sites are only short-lived campsprovided small inventories. So far, no traces of large, longer settled base camp types have been found. If this situation is not only the result of the current state of research, then it may suggest that the areas of south-eastern Poland were part of a larger territory exploited by some Magdalenian community. On the basis of the analysis, it may be assumed that this territory may have covered the areas of eastern Poland.

Magdalenian settlement in eastern Poland continues throughout the presence of Late Magdalenian societies in Central Europe, from Dryas I to Alleröd. It means that the population, or traditions of this culture, reached the eastern periphery relatively quickly and for a long time. The question arises if the Magdalenian population, functioning in the eastern borderlands, occupied areas not covered by any previous settlement, and whether were there contacts between them and representatives of other traditions - Epigravettian, whose settlement extends east of today's Polish borders on the territory of Ukraine. Finally, the last question is whether the line of the San is the final eastern limit of Magdalenian.

This last question should be answered in the affirmatively, though not categorically. So far, we do not know of any Magdalenian sites from the areas east of Poland. The answer to the remaining questions is difficult. A certain light is being shed on them by the discovery of the site in Święte. The part of the site studied so far provided a small concentration of lithic artefacts - flakes and blades as well as several tools. These materials were described as Epigravettian. The TL dates obtained from the profile indicate that it is contemporary to the Magdalenian settlement. Perhaps, therefore the Magdalenian population who came to this area inhabited the areas that were occupied by the "Epigravettian" population? Perhaps we are also dealing with a zone penetrated by both these communities? So far, we know only one Epigravettian site from this area, which is contemporary to the Magdalenian settlement, but its significance in the discussion of Magdalenien-Epigravettian relations is very important.

To what extent this borderland was the area of contacts and what the consequences could have been is unexplained yet. Apart from the few possible imports of Volhynian flint in Magdalenian inventories (Wierzawice, Grodzisko Dolne?), there are no other elements that could be a material confirmation of such contacts. An in-depth analysis of possible contacts on the west-east axis is also hindered by the poor level of recognition of the Polish-Ukrainian borderland on the Ukrainian side. 
Research conducted in the south-east of Poland shows that the Polish-Ukrainian borderland is an important area through which the border between two cultural traditions passes at the beginning of the Late Pleistocene. This is an extremely important area in discussion on the relationship between Magdalenian and Epigravettian. Today's knowledge and questions set the prospects for further work.

Key words: Epigravettian, Magdalenian, Upper Paleolithic, South-Eastern Poland, Polish-Ukrainian borderland, cultural contacts, imports.

The territories of south-eastern Poland, understood here generally as the areas of today's Podkarpackie Voivodeship, the same as the areas of western Ukraine bordering with them, were for years on the margin of research on the Palaeolithic. This situation caused that these areas are poorly recognized in this respect. However, during the last years the intensification of the Palaeolithic research arose, as a result of which several new sites have been discovered. The most of them could be related with the beginning of Late Pleistocene.

The terrains of Poland, located north of the Carpathians and the Sudetes, have been almost completely abandoned during the period of the LGM sensustricte. It is possible that episodic stays were limited only to expeditions connected with the acquisition of flint raw materials. This activities can be confirmed by the workshops from Kraków-Spadzista B + B1 and Piekary near Kraków [Wilczyński, 2007a, 2007b, 2006]. The hunter-gatherer societies withdrew after about 22 millennium $\mathrm{BP}$ from these lands southward, beyond the arch of the Carpathians and to the east - to the territory of present - day Ukraine. The testimony of migration to the east is probably a poor site from Przemyśl, Słowackiego street (formerly the Teich brickyard) [Kozłowski, 1963, Osiński, 1932, Połtowicz, 2004], excavated before 1939, and defined as exemplar of the Kostienki-Avdieyevo culture, referring to the assemblages from Kraków Spadzista street [Wojtal et al., 2015]. It seems that the areas of western Ukraine, just like the areas located to the south of the Carpathians and the Sudetes, were refugia for the Gravettian population retreating as the climate and environmental conditions deteriorated.

The reoccupation of Polish territories took place not until the end of LGM. These areas were then settled by the societies of the Magdalenian complex - a tradition that included upland areas of Western and Central Europe. On the basis of today's state of knowledge, it can be concluded that the eastern borders of Poland are at the same time the eastern boundary of the Magdalenien settlement [Połtowicz-Bobak, 2013]. Apart from a short episode from the Maszycka Cave, which is of older age [Kozłowski et al., 2012], the settlement lasts in Poland, the same as in the resto of the Central Europe, from the oldest Dryas to the early phase of the Alleröd interstadial [Bobak and Połtowicz-Bobak, 2013].

Five Magdalenian sites from the areas of today's Podkarpackie Voivodship are known (fig. 1). In the 1940s, a single-row harpoon linked to Magdalenian was found in Przemyśl [Kozłowski, 1977]. Further discoveries of sites fall into the turn of the 20th and 21st centuries. Four of them have been discovered up to this day: in Hłomcza [Valde-Nowak and Muzyczuk, 2000], Grodzisko Dolne [Czopek, 1999], Wierzawice [Bobak et al., 2017, 2010] and Łąka [Połtowicz-Bobak et al., 2014]. These sites usually provided small inventories, two of them - Łąka and Grodzisko Dolne were most probably only partially explored.

The richest and best preserved site in Wierzawice is an example of a typical hunting camp, which was settled for a short time, probably a few days or weeks. The remains of a fireplace with a stone construction and some concentrations of flint artefacts have been discovered at the site (fig. 2). Around the fireplace there are small concentrations of debit age and tools, especially lithic weaponry (fig. 3), at a greater distance - the place where the cores were processed. On the outskirts, large spots of red ochre were identified - it is probably the place of some activity, possibly related to the processing of organic raw materials [Bobak et al., 2017].

The second of the most important sites was discovered in Hłomcza in the Carpathians. This is a small, also shortly used seasonal camp. A structure interpreted as a dwelling was found here as well as a small inventory containing a few cores and tools (mostly burins), and almost no weapon inserts only 3 backed blade lets (fig. 4 ). 
The other two sites - Łąka (fig. 5) and Grodzisko Dolne (fig. 6) have been heavily destroyed and we only have residual lithic inventories. In Łąka, these artefacts form a small kshemenitsa. It seems that in these cases we should also talk about small, short-lived camps.

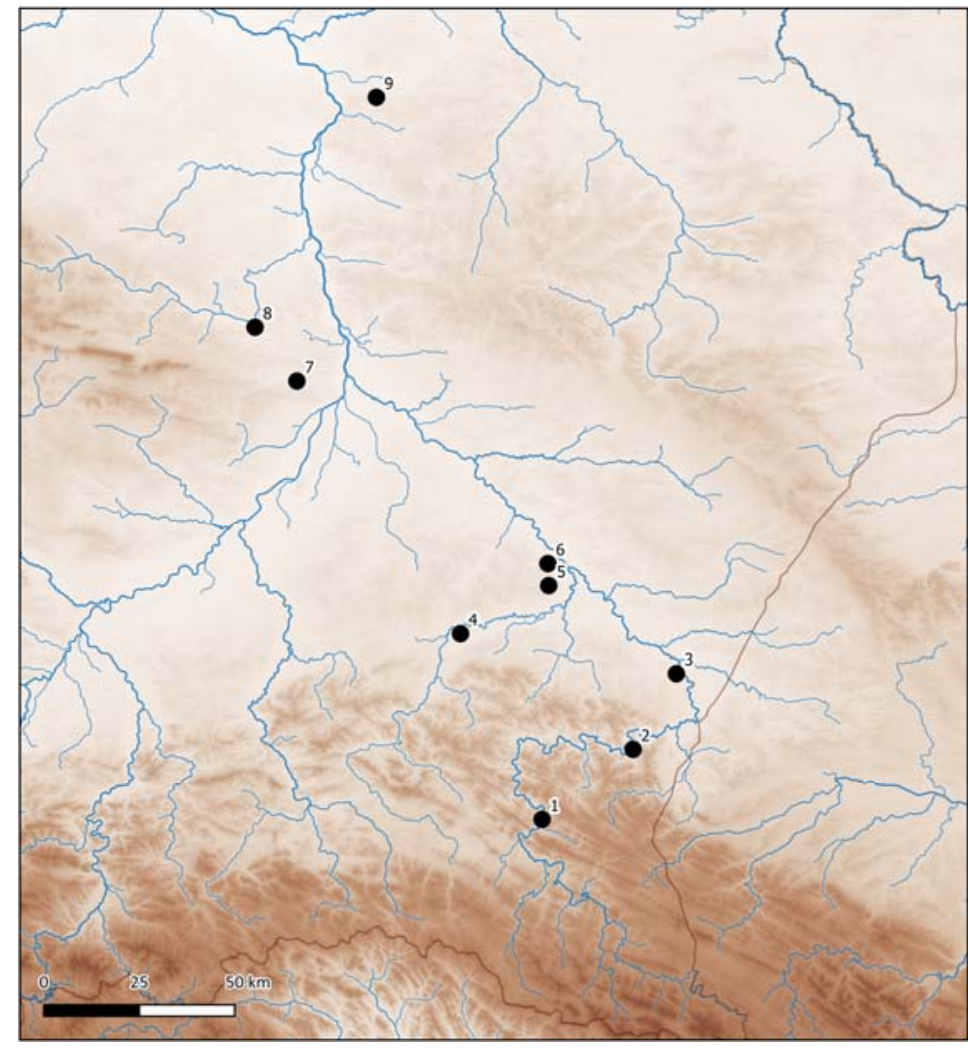

Fig. 1. Magdalenian and Epigravettian sites in eastern Poland mentioned in the text: 1 - Hłomcza, 2 - Przemyśl, 3-Święte, 4 - Łąka, 5 - Grodzisko Dolne, 6 - Wierzawice, 7 - Wilczyce, $\boldsymbol{8}$ - Ćmielów-Mały Gawroniec, 9 - Klementowice (draw by D. Bobak)

Рис. 1. Мадленські та епіграветські стоянки у східній Польщі, згадані у тексті: 1 - Гломча, 2 - Перемишль, 3 - Сьвенте, 4 - Лонка, 5 - ГродзіськоДольне, 6 - Віравиці, 7 - Вільчице, 8 - Хмельов-Малий Гавронець, 9- Клементовіце (рис. за Д. Бобаком)

The sites examined so far are only short-lived camps. So far, no traces of large, longer settled base camp types have been found. If this situation is not only the result of the current state of research, then it may suggest that the areas of south-eastern Poland were part of a larger territory exploited by some Magdalenian community and constituted mainly hunting areas. On the basis of the analysis, it may be assumed that this territory may have covered the areas of eastern Poland up to the Nałęczów Plateau, from where a large camp in Klementowice (Lublin province) is known [Wiśniewski, 2015, Wiśniewski et al., 2012]. It is likely that this common territory also covers areas located on the west side of the Vistula River, in the Sandomierz Basin, from which large sites are known in Wilczyce [Schild, 2014] and Ćmielów - Mały Gawroniec [Przeździecki et al., 2011]. Relations with this areas are well attested by raw materials used in sites in Wierzawice, Łąka and Grodzisko Dolne (chocolate and Świeciechów flint).

Magdalenian settlement in eastern Poland continues throughout the presence of Late Magdalenian societies in Central Europe, from Dryas I (Klementowice) to Alleröd (Wierzawice). It means that the population, or traditions of this culture, reached the eastern periphery relatively quickly and for a long time. The question arises if the Magdalenian population, functioning in the 
eastern borderlands, occupied areas not covered by any previous settlement, and whether were there contacts between them and representatives of other traditions - Epigravettian, whose settlement extends east of today's Polish borders on the territory of Ukraine. Finally, the last question is whether the line of the San and the Bug is the final eastern limit of Magdalenian.

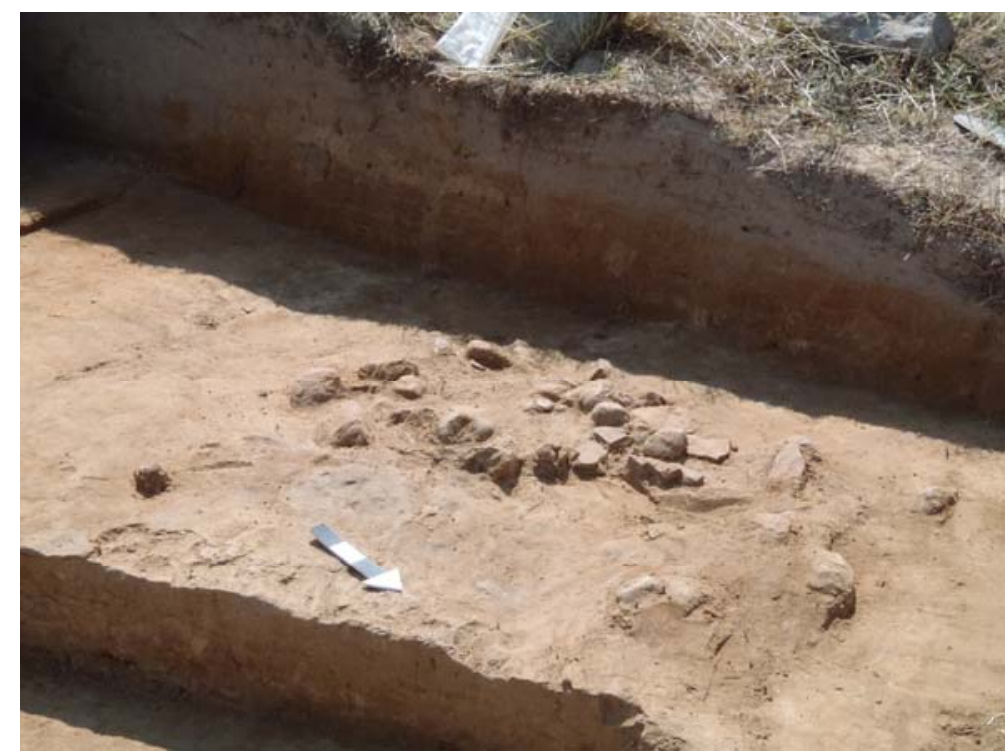

Fig. 2. Wierzawice site. Fireplace during excavations (foto D. Bobak)

Рис. 2. Стоянка Віравиці. Вогнище у процесі розчистки (фото Д. Бобака)

This last question should be answered in the affirmatively, though not categorically. So far, we do not know of any Magdalenian sites from the areas east of Poland. This can be explained by the state of the research but also by the fact that this area was already the zone in habited by another large cultural complex - Epigravettian [Григорьева and Клапчук, 1981; Нужный, 2015].

The answer to the remaining questions is difficult. A certain light is being shed on them by the discovery of the site in Święte. The part of the site studied so far provided a small concentration of lithic artefacts - flakes and blades as well as several tools. These materials were described as Epigravettian. The TL dates obtained from the profile indicate that it is contemporary to the Magdalenian settlement (unpublished researches of the team under the direction of the authors). Perhaps, therefore the Magdalenian population who came to this area inhabited the areas that were occupied by the "Epigravettian" population? Perhaps we are also dealing with a zone penetrated by both these communities? With the population density at this time, such a situation was not only possible, but even these groups could not meet. This region could thus be at the same time a border and a zone of intercultural contacts. So far, we know only one Epigravettian site from this area, which is contemporary to the Magdalenian settlement, but its significance in the discussion of MagdalenienEpigravettian relations is very important.

To what extent this borderland was the area of contacts and what the consequences could have been is unexplained yet. Eastern cultural influences have evidences only in the form of single imports of Volhynian flints, often doubtful. It is not possible to determine whether their occurrence in inventories is the result of the presence of the Magdalenian population in the areas located to the east of the today's known Magdalenian settlement border or as a result of exchanges between the Magdalenian and Epigravettian groups. Depending on the answer, it should be assumed that either 

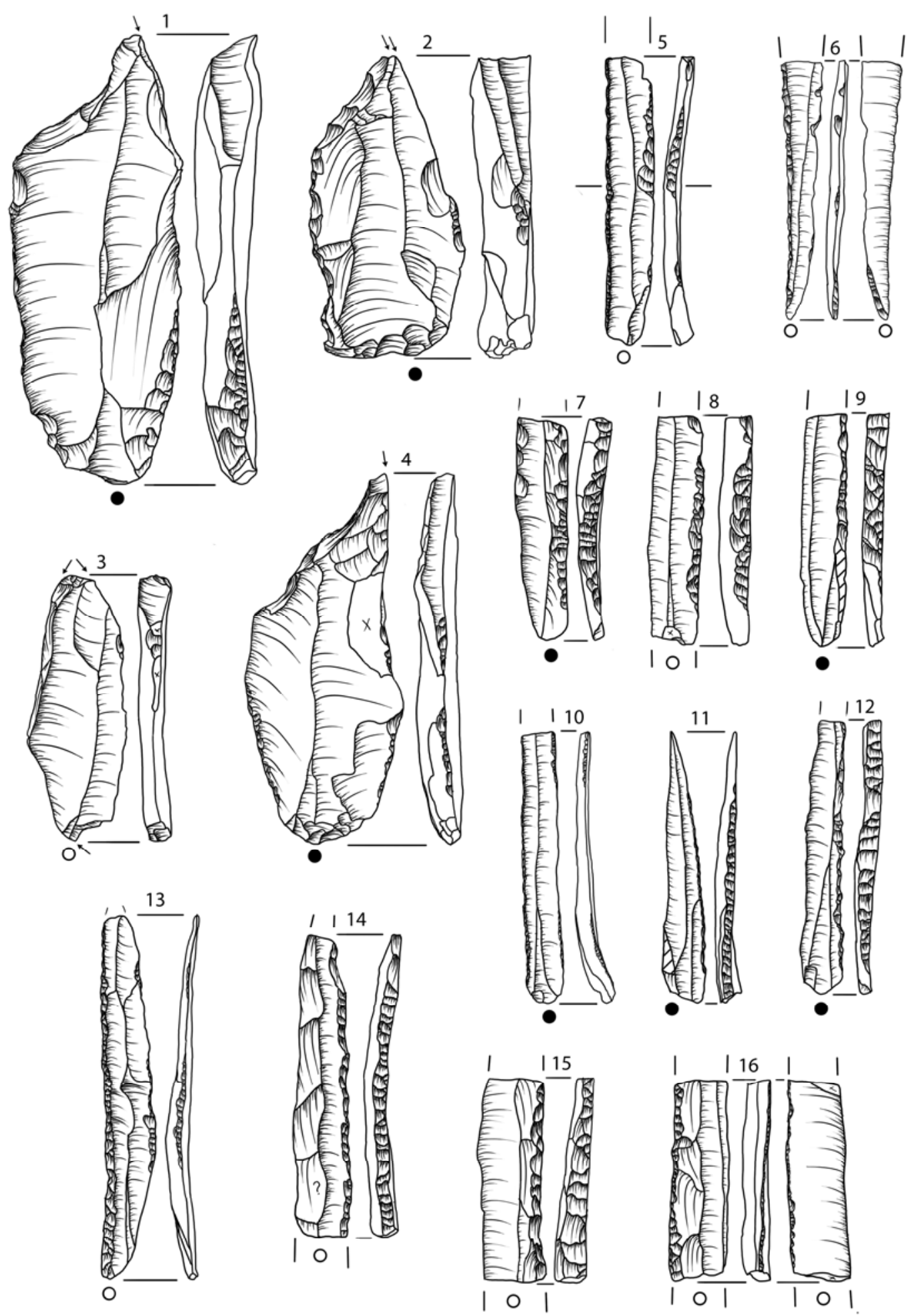

Fig. 3. Wierzawice site Lithic industry (after Bobak et al., 2017)

Рис. 3. Стоянка Віравиці. Кам’яні вироби (за Bobak et al., 2017) 

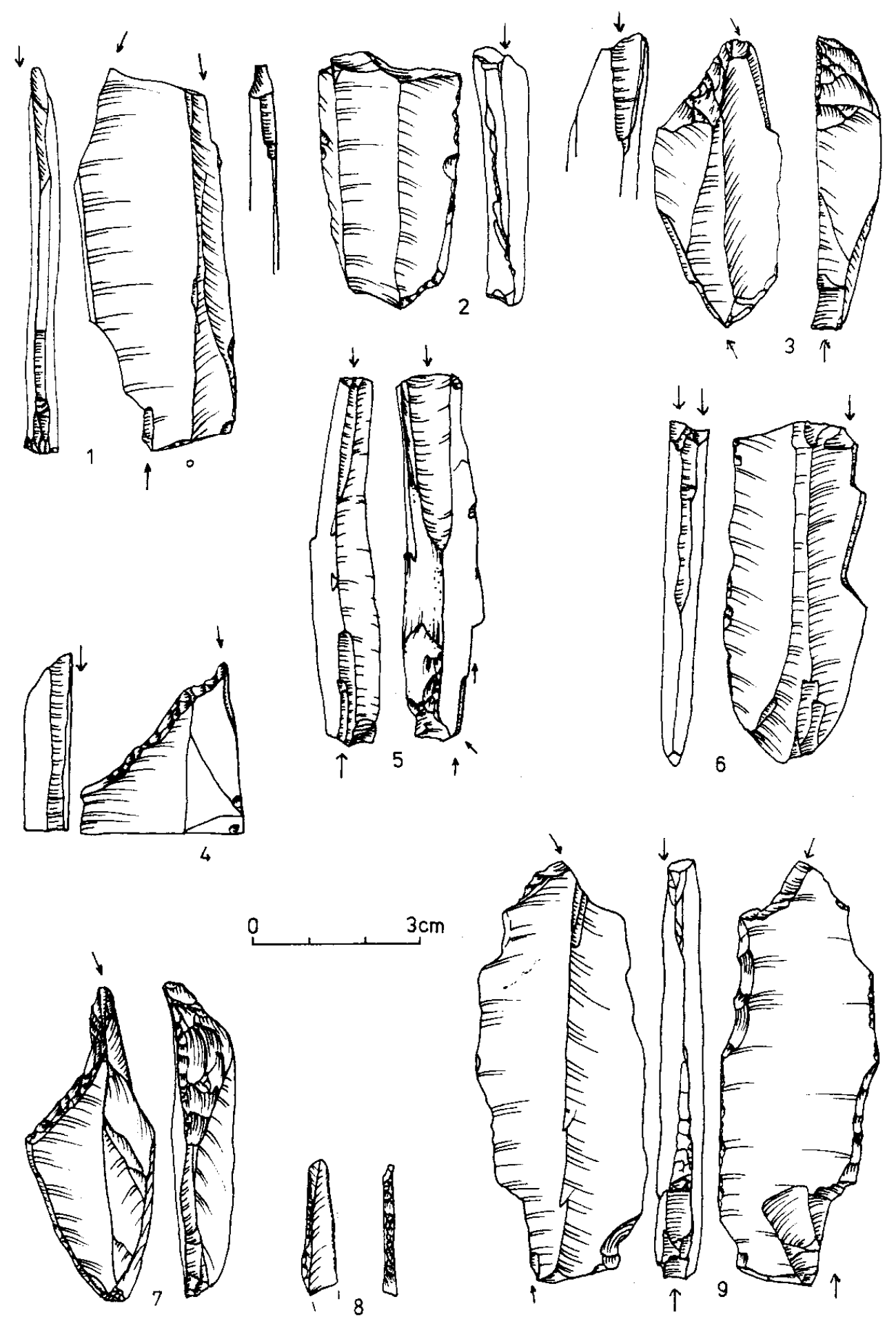

Fig. 4. Hłomcza site. Lithic industry (after Valde-Nowak, Muzyczuk, 2000)

Рис. 4. Стоянка Гломча. Кам’яні вироби (за Valde-Nowak, Muzyczuk, 2000) 

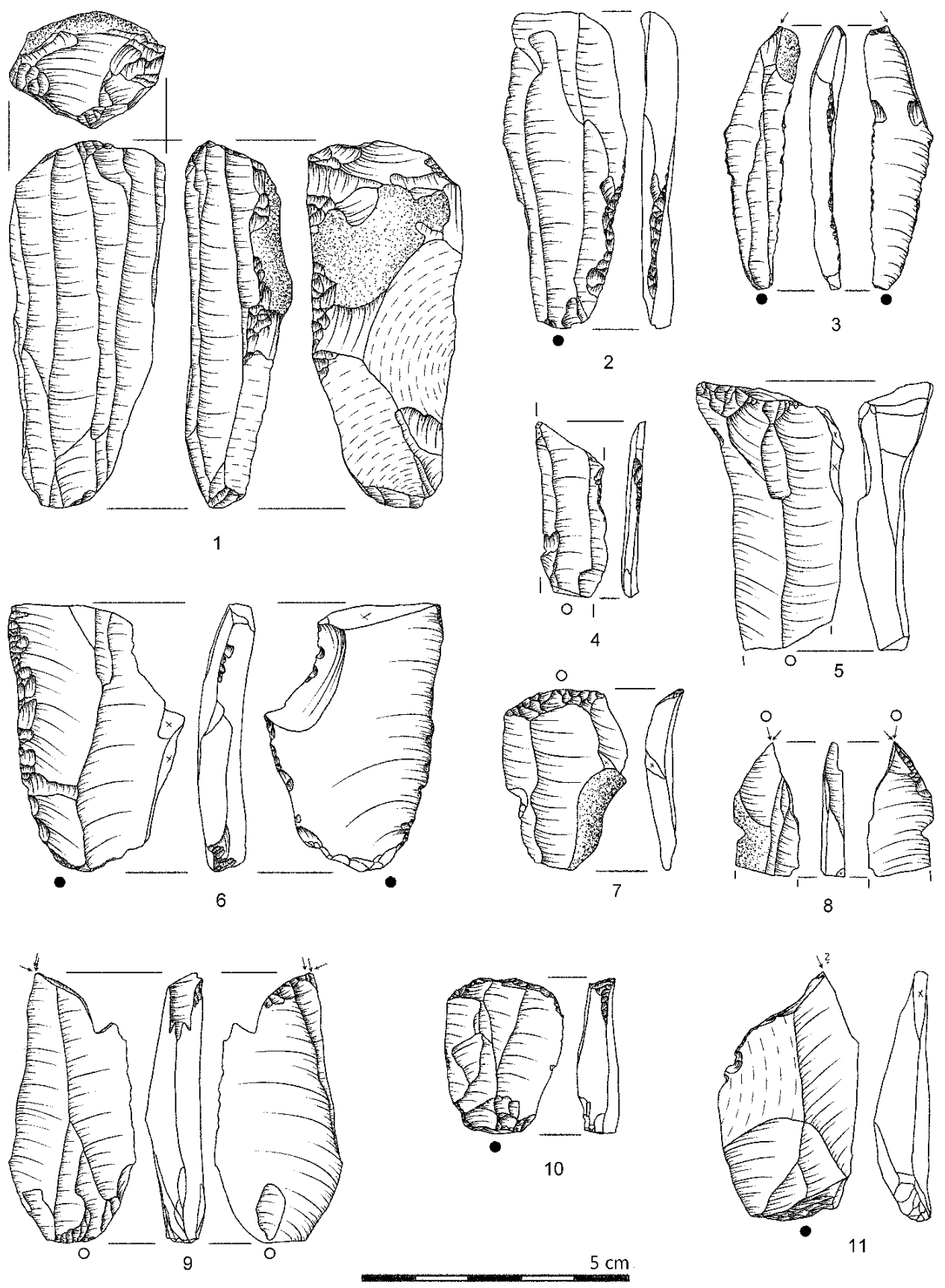

Fig. 5. Łąka site. Lithic industry (after Połtowicz-Bobak et al., 2014, ryc. 8)

Рис. 5. Стоянка Лонка. Кам’яні вироби (за Połtowicz-Bobak et al., 2014, ryc. 8) 


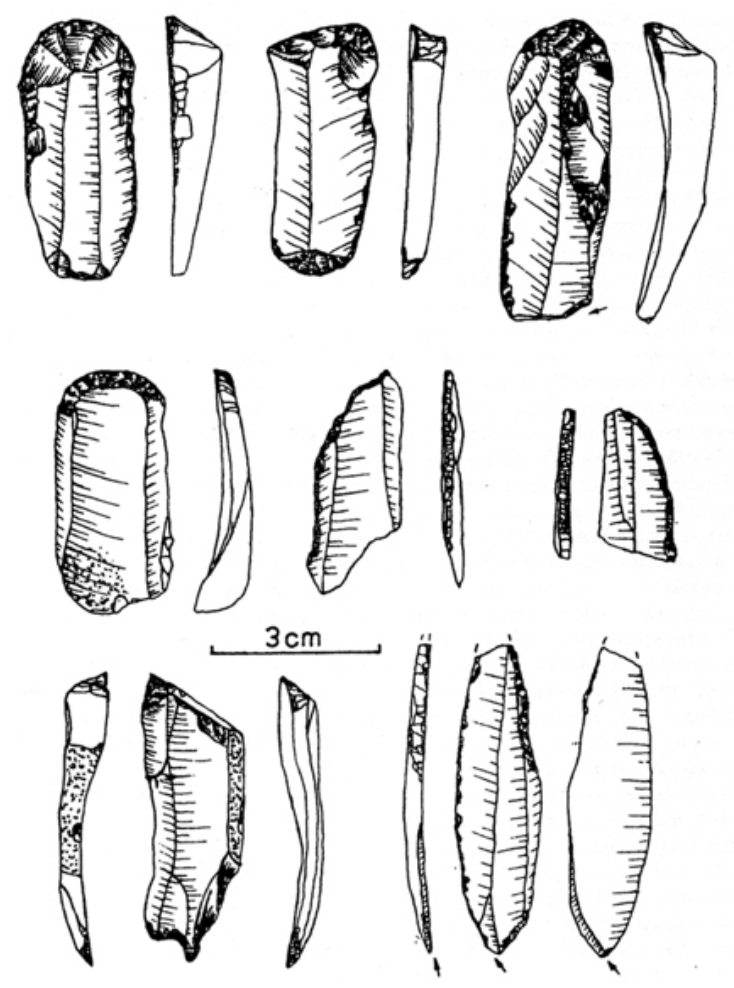

Fig. 6. Grodzisko Dolne site. Lithic industry (after S. Czopek 1999)

Рис. 6. Стоянка Гродзісько-Дольне. Кам'яні вироби (за S. Czopek 1999)

relationship between Magdalenian and Epigravettian. The results of the research allow asking important questions. To get closer to the answers, further intensive research is needed both on the Polish and Ukrainian side of the border. Today's knowledge and questions set the prospects for further work.

\section{ЛIТЕРАТУРА}

Григорьева Г. В., Клапчук М. Н. (1981). Позднепалеолитическая стоянка Межигирцы І в ИваноФранковской области // Краткие сообщения Института археологии АН СССР. - Вып. 165. - С. 58-63.

Нужный Д.Ю. (2015). Верхній палеоліт Західної і Північної Україны (техніко-типологічна варіабельність та періодизація). - Київ: Інститут Археології НАНУ.

Bobak D., Lanczont M., Mroczek P., Połtowicz-BobakM., NowakA., Kufel-Diakowska B., KusiakJ., Standzikowski K. (2017). Magdalenian settlement on the edge of the loess island: A case study from the northern foreland of the Carpathians (SE Poland) // Quaternary International. - Vol. 438. - P. 158-173. Режим доступу: https://doi.org/10.1016/j.quaint.2017.04.034

Bobak D., Eanczont M., Nowak A., Połtowicz-Bobak M., Tokarczyk S. (2010). Wierzawice st. 31 - nowy ślad osadnictwa magdaleńskiego w Polsce południowo-wschodniej // Materiały i Sprawozdania Rzeszowskiego Ośrodka Archeologicznego. - T. XXXI. - S. 63-78.

Bobak D., Poltowicz-Bobak M. (2013). Bayesian age modelling of the Magdalenian settlement in the territory of present-day Poland // Rech. Archéologiques Nouv. - Sér. 5-6. - P. 51-67.

Czopek S. (1999). Pradzieje Polski południowo-wschodniej. - Rzeszów: Wydawnictwo Uniwersytetu Rzeszowskiego. $-217 \mathrm{~s}$. 
Kozłowski J. K. (1963). Z zagadnień paleolitu Polski południowo-wschodniej // Rocznik województwa rzeszowskiego. - Vol. III. - S. 5-18.

Kozłowski S. K. (1977). Harpun ze stanowiska Przemyśl II // Acta Archaeologica Carpathica. Vol. XVII. - S. 139-143.

Kozłowski S. K., Połtowicz-Bobak M., Bobak D., Terberger T. (2012). New information from Maszycka Cave and the Late Glacial recolonisation of Central Europe // Quaternary International. - Vol. 272-273. P. 288-296. [Електронний ресурс]. Режим доступу: https://doi.org/10.1016/j.quaint.2012.02.052

Osiński K. (1932). Najstarsze ślady człowieka dyluwialnego w Przemyślu // Ziemia. - T. 19. - S. 278.

Połtowicz M. (2004). Ślady łowców mamutów i wyspecjalizowanych myśliwych na terenie Przemyśla, in: Dzieje Przemyśla. Tom I Osadnictwo Pradziejowe i Wczesnośredniowieczne. Część II - Analiza Źródeł i Synteza / Ed. Koperski, A. - Przemyśl. - S. 5-17.

Poltowicz-Bobak M. (2013). Wschodnia prowincja magdalenienu. - Rzeszów: Wydawnictwo Uniwersytetu Rzeszowskiego.

Połtowicz-Bobak M., Bobak D., Gębica P. (2014). Nowy ślad osadnictwa magdaleńskiego w Polsce południowo-wschodniej. Stanowisko Łąka 11-16 w powiecie rzeszowskim // Materiały i Sprawozdania Rzeszowskiego Ośrodka Archeologicznego. - T. XXXV. - S. 237-248.

Przeździecki M., Migal W., Krajcarz M., Pyżewicz K. (2011). Ćmielów, st. 95 ("Mały Gawroniec”), woj. świętokrzyskie. Badania w roku 2009 // Światowit. - T. VIII (XLIX) (2009-2010). - S. 191-193.

Wilczyce. A Late Magdalenian Winter Hunting Camp in Southern Poland. (2014). / Ed. Schild R. Warszawa.

Valde-Nowak P., Muzyczuk A. (2000). Magdalenien Settlement at Hłomcza (Polish Carpathians) // Acta Archaeologica Carpathica. - Vol. XXXV (1999-2000). - S. 5-32.

Wilczyński J. (2007a). Epigrawecka pracownia krzemienia na stanowisku Kraków ul. Spadzista B+B1// Przegląd Archeologiczny. - Vol. 55. - S. 5-52.

Wilczyński J. (2007b.) The Gravettian and Epigravettian lithic assemblage from Kraków-Spadzista B+B1:dynamic approach to the technology // Folia Quat. - Vol. - 77. - S. 37-96.

WilczyńskiJ. (2006). The upper palaolithic workshop at the site Piekary IIa sector XXII layer 5 // Sprawozdania Archeologiczne. - T. 58. - S. 175-203.

Klementowice. A Magdalenian site in eastern Poland. (2015). / Ed. Wiśniewski T. - Lublin: Institute of Archaeology Maria Curie-Skłodowska University in Lublin

Wiśniewski T., Mroczek P., Rodzik J., Zagórski P., Wilczyński J., Fišáková M.N. (2012). On the periphery of the Magdalenian World: An open-air site in Klementowice (Lublin Upland, Eastern Poland) // Quaternary International. - Vol.272-273. - P.308-321. [Електронний pecypc]. Режим доступу: https://doi.org/10.1016/j.quaint.2012.06.032

Wojtal P., Wilczyński J., Sobczyk K. (2015). A new look at an old site: studies of the Kraków-Spadzistasie 1968-2013, in:. Forgotten Times and Spaces. New Perspectives in Paleoetnological and Archeological Studies. I Eds. Sázelová, S., Novak, M., Mizerová, A. - Brno: Institute of Archeology of the Czech Academy of Sciences; Masaryk University. - Pp. 169-190.

\section{REFERENCES}

Grigor'eva, G. V., Klapchuk, M. N. (1981). Pozdnepaleoliticheskaja stojanka Mezhigircy I v IvanoFrankovskoj oblasti. Kratkie Soobshhenija Instituta Arheologii Akademii nauk USSR, 165, 58-63 (in Russian).

Nuzhnyi, D. Yu. (2015). Verkhnii paleolit Zakhidnoi i Pivnichnoi Ukrainu (tekhniko-typolohichna variabelnist ta periodyzatsiia). Kyiv: Instytut Arkheolohii Natsionalna akademiia nauk Ukrainy. (in Ukrainian).

Bobak, D., Łanczont, M., Mroczek, P., Połtowicz-Bobak, M., Nowak, A., Kufel-Diakowska, B., Kusiak, J., \& Standzikowski, K. (2017). Magdalenian settlement on the edge of the loess island: A case study from the northern foreland of the Carpathians (SE Poland). Quaternary International, 438, 158-173. https://doi.org/10.1016/j.quaint.2017.04.034

Bobak, D., Łanczont, M., Nowak, A., Połtowicz-Bobak, M., \& Tokarczyk, S. (2010). Wierzawice st. 31 nowy ślad osadnictwa magdaleńskiego w Polsce południowo-wschodniej. Materiały $i$ Sprawozdania Rzeszowskiego Ośrodka Archeologicznego, 31, 63-78 (in Polish). 
Bobak, D., \& Połtowicz-Bobak, M. (2013). Bayesian age modelling of the Magdalenian settlement in the territory of present-day Poland. Rech. Archéologiques Nouv, 5, 51-67.

Czopek, S. (1999). Pradzieje Polski południowo-wschodniej. Rzeszów: Wydawnictwo Uniwersytetu Rzeszowskiego, 217 (in Polish).

Kozłowski, J. K. (1963). Z zagadnień paleolitu Polski południowo-wschodniej. Rocznik województwa rzeszowskiego, 3, 5-18 (in Polish).

Kozłowski, S. K. (1977). Harpun ze stanowiska Przemyśl II. Acta Archaeologica Carpathica, 17, 139-143 (in Polish).

Kozłowski, S. K., Połtowicz-Bobak, M., Bobak, D., \& Terberger, T. (2012). New information from Maszycka Cave and the Late Glacial recolonisation of Central Europe. Quaternary International, 272-273, 288296. https://doi.org/10.1016/j.quaint.2012.02.052

Osiński, K. (1932). Najstarsze ślady człowieka dyluwialnego w Przemyślu. Ziemia, 19, 278 (in Polish).

Połtowicz, M. (2004). Ślady łowców mamutów i wyspecjalizowanych myśliwych na terenie Przemyśla. In Koperski, A. (Ed.), Dzieje Przemyśla. Tom I Osadnictwo Pradziejowe $i$ Wczesnośredniowieczne. Część II Analiza Źródeł i Synteza (pp. 5-17). Przemyśl. (in Polish).

Połtowicz-Bobak, M. (2013). Wschodnia prowincja magdalenienu. Rzeszów: Wydawnictwo Uniwersytetu Rzeszowskiego. (in Polish).

Połtowicz-Bobak, M., Bobak, D., \& Gębica, P. (2014). Nowy ślad osadnictwa magdaleńskiego w Polsce południowo-wschodniej. Stanowisko Łąka 11-16 w powiecie rzeszowskim. Materiały $i$ Sprawozdania Rzeszowskiego Ośrodka Archeologicznego, 35, 237-248 (in Polish).

Przeździecki, M., Migal, W., Krajcarz, M., Pyżewicz, K. (2011). Ćmielów, st. 95 (“Mały Gawroniec”), woj. świętokrzyskie. Badania w roku 2009. Światowit, 8(49) (2009-2010), 191-193 (in Polish).

Schild, R. (Ed.). (2014). Wilczyce. A Late Magdalenian Winter Hunting Camp in Southern Poland. Warszawa.

Valde-Nowak, P., Muzyczuk, A. (2000). Magdalenien Settlement at Hłomcza (Polish Carpathians). Acta Archaeologica Carpathica, 35 (1999-2000), 5-32 (in English, \& in Polish).

Wilczyński, J. (2007a). Epigrawecka pracownia krzemienia na stanowisku Kraków ul. Spadzista B+B1. Przegląd Archeologiczny, 55, 5-52 (in Polish).

Wilczyński, J. (2007b.) The Gravettian and Epigravettian lithic assemblage from Kraków-Spadzista B+B1:dynamic approach to the technology. Folia Quat, 77, 37-96.

Wilczyński, J. (2006). The upper palaolithic workshop at the site Piekary IIa sector XXII layer 5. Sprawozdania Archeologiczne, 58, 175-203 (in English, \& in Polish).

Wiśniewski, T. (Ed.). (2015). Klementowice. A Magdalenian site in eastern Poland. Lublin: Institute of Archaeology Maria Curie-Skłodowska University in Lublin

Wiśniewski, T., Mroczek, P., Rodzik, J., Zagórski, P., Wilczyńsk,i J., \& Fišáková, M.N. (2012). On the periphery of the Magdalenian World: An open-air site in Klementowice (Lublin Upland, Eastern Poland). Quaternary International, 272-273, 308-321.

https://doi.org/10.1016/j.quaint.2012.06.032

Wojtal, P., Wilczyński, J., Sobczyk, K. (2015). A new look at an old site: studies of the KrakówSpadzistasie 1968-2013. In S. Sázelová, M. Novak, \& A. Mizerová (Eds.). Forgotten Times and Spaces. New Perspectives in Paleoetnological and Archeological Studies (pp. 169-190). Brno: Institute of Archeology of the Czech Academy of Sciences; Masaryk University. 


\title{
МІЖ МАДЛЕНОМ ТА ЕПІГРАВЕТОМ. ВНЕСОК У ДОСЛІДЖЕННЯ ПАЛЕОЛІТУ НА ПОЛЬСЬКО-УКРАЇНСЬКОМУ ПОГРАНИЧЧІ
}

\author{
Даріуш БОБАК', Марта ПОЛТОВІЧ-БОБАК \\ ${ }^{1}$ Фундація Жешівського археологічного осередку \\ вул. Монюшка, 10, 350015, м. Жешів, Польща, e-mail: dbobak@lithics.eu \\ ${ }^{2}$ Інститут археологї Жешівського університету, \\ вул. Монюшка, 10, 350015, м. Жешів, Польща, e-mail: mpoltowicz@lithics.eu
}

Територія Польщі на північ від Карпат та Судет була майже безлюдною впродовж останнього льодовикового максимуму (у вузькому розумінні). Повторне заселення території Польщі відбулось не раніше фіналу останнього льодовикового максимуму. В означений період цей регіон був освоєний спільнотами мадленського комплексу - традиції, носії якої заселяли височини Західної та Центральної Європи. Грунтуючись на доступних на сьогоднішній день джерелах, можна зробити висновок, що східний кордон Польщі у досліджувану епоху став також східною межею поширення мадленських спільнот.

На землях сучасного Підкарпатського воєводства відомо п’ять мадленських стоянок. У 1940-х однорядний гарпун з промовистими мадленськими рисами виявлено у Перемишлі. Нові стоянки відкрито на межі XX-XXI ст. Чотири з них знайдено зовсім недавно: Гломча, Гродзісько-Дольне, Віравиця та Лонка.

Ці пам'ятки існували впродовж дуже короткого відрізку часу, їх культурний шар слабко насичений артефактами. Решток довготривалого стійбища досі не виявлено. Якщо причиною цього є не лише недостатнє вивчення регіону, можна зробити припущення, що територія Південно-Східної Польщі у окреслений період становила лише невелику частину більшого ареалу проживання певної мадленської спільноти. Грунтуючись на проведених аналізах, можна зробити висновок, що цей ареал включав області Східної Польщі.

Мадленське заселення Східної Польщі відбувалось у рамках поширення пізньомадленських спільнот по території Східної Європи у період від дріасу I до алерьоду. Це означає, що населення або традиція цієї культури сягнули своєї східної периферії порівняно швидко та затримались тут надовго. Виникає питання, чи проживали на землях східного пограниччя, зайнятих мадленським населенням, які-небудь давніші спільноти, та чи взагалі мали місце контакти між ним та носіями інших традицій епіграветських, стоянки яких займали території сучасної України на схід від польського кордону. Нарешті, останнє питання: чи був басейн р.Сян крайньою межею поширення представників мадленської традиції?

На нього можна дати ствердну, хоча й не категоричну відповідь. Принаймні до цього часу ми не знаємо жодної мадленської стоянки на землях східніше від кордонів Польщі. Відповідь на решту питань дати значно складніше. Частково світло на них проливає відкриття стоянки Святе. Частина території пам'ятки, досліджена на цей час, характеризується слабкою насиченістю культурного шару кам'яними артефактами - відщепами і пластинами та невеликим набором знарядь. Ці матеріали віднесено до епігравету. Одержані з профілю стоянки ТЛ-дати свідчать про синхронність їі матеріалів та мадленських пам'яток. Отже, ймовірно, мадленське населення, яке прийшло на цю територію, зайняло землі, заселенні “епіграветськими” спільнотами? А можливо, ми маємо справу із зоною, у яку проникали представники обох традицій? На цей момент нам відома лише одна епіграветська стоянка на цій території, синхронна із мадленськими пам'ятками, але іiі значення для дискусії щодо мадленськоепіграветських контактів надзвичайно велике.

До якої міри це пограниччя було контактною зоною та якими могли бути наслідки досі, невідомо. Попри нечисельні випадки можливих імпортів волинського кременю у мадленських збірках (Віравиці, Гродзіско-Дольне?), немає жодного археологічного підтвердження такого роду контактів. Поглиблений аналіз ймовірних впливів, спрямованих із заходу на схід, ускладнений недостатнім рівнем дослідження зони польсько-українського пограниччя з українського боку. 
Дослідження проведені у Південно-Східній Польщі, демонструють, що польсько-українське порубіжжя було важливим регіоном, через який на початку пізнього плейстоцену проходив кордон між двома культурними традиціями. Ця територія також надзвичайно важлива для дискусії щодо взаємовідносин між мадленськими та епіграветськими спільнотами. Таким чином, актуальні знання та існуюча проблематика окреслюють перспективи для подальших досліджень.

Ключові слова: епігравет, мадлен, верхній палеоліт, Південно-Східна Польща, польськоукраїнське пограниччя, міжкультурні контакти, імпорти. 